\title{
THE INFLUENCE OF LIFESTYLE FACTORS ON CONSTIPATION - SHOULD THE PHARMACIST BE AWARE OF THIS?
}

\author{
R. Minkutè, I. Andrijauskaitè, V. Briedis
}

\begin{abstract}
Метою иьього дослідження був аналіз впливу способу життя (харчування та фізичних навантажень) на закреп та оцінка ставлення респондентів до цього розладу.

Методи. Відвідувачі аптеки, які погодились відповісти на запитання, були включені у дослідження. Проаналізовано дані респондентів на основі віку (18-45 років; 46-65 років; старше 65 років) та індексу маси тіла ("нормально", "надмірна вага", "ожиріння"). Харчування та фізичні навантаження були проаналізовані з метою виявлення факторів ризику появи закрепу. Була використана описова та порівняльна статистика - відповіді респондентів представлені частотами та відсотками, Хі-квадратний тест був виконаний для вимірювання асоиіації зі знаннями, відповідями та статтю, віком, IМТ.

Результати. У ході дослідження було встановлено $12.8 \%$ постійної частоти закрепів в досліджуваній групі, незалежно від статі, проте більшість чоловіків не мали проблем із закрепами (50.5\% проти $39.9 \%$ \%. Індекс маси тіла та вік був пов'язаний із закрепами (p<0.05). Споживання кави та / або чаю не було пов'язане із закрепами в досліджуваній групі, проте нерухомий спосіб життя респондентів був пов'язаний із постійними та випадковими закрепами (75.0\% та 41.1\%, відповідно) (p<0.05).

Висновки. У цьому дослідженні були визначені споживання вуглеводів, недостатнє споживання рідини та нерухомий спосіб життя як фактори ризику розвитку закрепу. Рекомендації щзодо зміни способу життя можуть бути включені до консультацій провізорів
\end{abstract}

Ключові слова: частота закрепів, харчування, фізичні навантаження, індекс маси тіла

Copyright (C) 2019, R. Minkutè, I. Andrijauskaitè, V. Briedis. This is an open access article under the CC BY license (http://creativecommons.org/licenses/by/4.0).

\section{Introduction}

Constipation is a quite common disorder in people. Sometimes it is considered to be a minor health problem and not sufficient attention is given to it. The prevalence of this disorder is difficult to assess, as only a small proportion of the population suffering from constipation actually seek medical attention [1]. However, constipation usually is diagnosed for the people between the ages of 50 and $70[2,3]$, and untreated problem can lead to other diseases [4]. This disorder adversely affects human health, immunity, develops oxidative stress when free radicals attack cells and can cause irreversible damage [5]. Studies have shown that constipation is equated with diabetes, cardiovascular disease, osteoarthritis, or depression $[6,7]$, it is more common than hypertension, migraine, obesity, or diabetes [8], moreover, constipation was identified as a risk factor for Parkinson's disease [9]. It was found that laxatives are used more often than antidepressants, analgesics, and cardiovascular drugs [10].

A high prevalence of constipation, economic costs, adverse effects on health and quality of life indicate that it could be considered a major public health problem [11]. This can have both a direct and an indirect impact on health costs. Directly, the identification and treatment of constipation; indirectly, employee absence from work, and reduced productivity $[11,12]$. In the United States in 2012, 3.2 million people sought treatment for constipation and experienced significant expenses for related health care [13]. There is a lack of information on the confirmed symptoms of constipation, on lifestyle characteristics to prevent constipation, and on the results of conventional treatment therapy. Various treatments to relieve constipation symptoms are used, however up to $50 \%$ of the patients are dissatisfied with the outcome of the treatment due to safety and efficacy [14].

Risk factors for constipation include malnutrition, fluid intake and physical inactivity, although, recent studies in Japan found that fiber does not affect the intestine motility. A possible explanation is that there is too little dietary fiber intake, therefore no positive effect is achieved [15]. Studies have shown that physical activity was associated with a lower constipation rate [16, 17]. Epidemiological studies identified that people in sedentary work were 3 times more likely to experience constipation [12].

The aim of this study was to analyze the influence of the lifestyle (nutrition and physical activity) on constipation and evaluate the respondents' attitude to this disorder.

\section{Planning (methodology) of research}

This study was based on the researches performed by other scientists. As there was a limited number of studies with constipation in Lithuania, the planned study focused on the probable lifestyle factors influence on this disorder. To collect the information from persons about constipation the research method using questionnaires was chosen. The questionnaire was developed with closed questions about person's age, gender, weight and height, lifestyle (nutrition and physical activity). The 
study participants had to answer how long suffered from constipation, what measures were used for constipation relief, and if they were concerned about this disorder. The respondents were asked how they understand constipation and what reasons can influence it.

The study design and developed questionnaire was approved by Lithuanian Bioethics Committee (approval No. 6B-16-62). The study was conducted in Kaunas, Lithuania, the sample size (n) was calculated using the number of Kaunas citizens $(\mathrm{N}=297669)$ and the equation by Schwarze (1993):

$$
n=\frac{N \times 1.96^{2} \times p \times q}{\varepsilon^{2} \times(N-1)+1.96^{2} \times p \times q} ;
$$

where $\varepsilon$ is the desired level of precision $(\varepsilon=0.05)$; $\mathrm{p}$ is the (estimated) of the population which attribute in the investigated question - the constipation prevalence in Europe was used $(17 \%$; $=0.17)$; $q$ is $(1-p)$, the value of 1.96 is $\mathrm{Z}$ value at $95 \%$ confidence level per the normal table. The calculated sample size was 215 , the number of collected questionnaires -250 .

Study data were analysed using non-parametric statistical methods and conclusions were drawn.

\section{Materials and Methods}

Subjects who visited a pharmacy and agreed to answer the questionnaire were included in the study. For data analysis, the subjects were distributed by age into three groups (18-45 years old; 46-65 years old; above 65 years old), and their body mass index (BMI) was calculated $\left(\mathrm{BMI}=\right.$ weight $(\mathrm{kg}) /$ height $\left.(\mathrm{m})^{2}\right)$. Respondents with a BMI in the 18-24.9 range - were named "normal;" in the 25-29.9 range - "overweight"; above 30 "obese." Two respondents (females) did not indicate their weight, so their BMI was not calculated and the results related to body mass index are presented for 141 females.

The respondents' nutrition was grouped according to dominated answers, i.e. proteins (meat, fish), carbohydrate (various porridges, flour products, cookies, cakes), mixed (proteins and carbohydrate), various (different diets, vegetarian, vegan). Vegetables consumption was analyzed "yes" or "no," depending upon the respondent's choice; liquids consumption - "less than 2 litres per day" or "more 2 litres per day," as well as the consumption of coffee and tea was evaluated "yes" or "no." The following groups were formed for analysis of physical activity: motionless, exercise, rare exercise (respondent confirmed low mobility lifestyle, however with few exercises sometimes).

Data were analyzed using Statistical Package for Social Sciences (SPSS) version 20. Descriptive and comparative statistics were employed - the respondents' responses are presented in frequencies and percentages. The responses were ordinal scaled; therefore, Chi-square test was executed to measure association with knowledge, responses and gender, age, BMI. P value less than 0.05 was considered to show significant association.

\section{Results}

The study involved 143 (57.2\%) females and 107 $(42.8 \%)$ males. The biggest group was with the respondents $18-45$ years old $(56.4 \%), 25.6 \%-45-65$ years old, and the rest $(18 \%)$ - above 65 years old. While analysing body mass index, it was identified that $53.2 \%$ of respondents had a normal BMI, $40.8 \%$ - overweight and $5.2 \%$ - obese. The distribution of BMI by age in females and males is presented the Fig. $1,2(\mathrm{p}<0.05)$. The respondents from both gender groups up to 45 years old were of a normal BMI, however, overweight dominated in the older groups.

Constipation frequency in the study group is presented in Tab. 1. There were no differences between females and males, although more males did not have constipation problem (50.5 \% vs $39.9 \%)$. However, constipation depended on the age $(\mathrm{p}<0.05)$ - the majority with no constipation was in the 18-45 years old group, over $90 \%$ of respondents suffered from constipation in the group above 65 years old. Analysis of constipation frequency by body mass index showed that more respondents with constant constipation were in the "obese" group; however, occasional constipation was confirmed in the "normal" group.

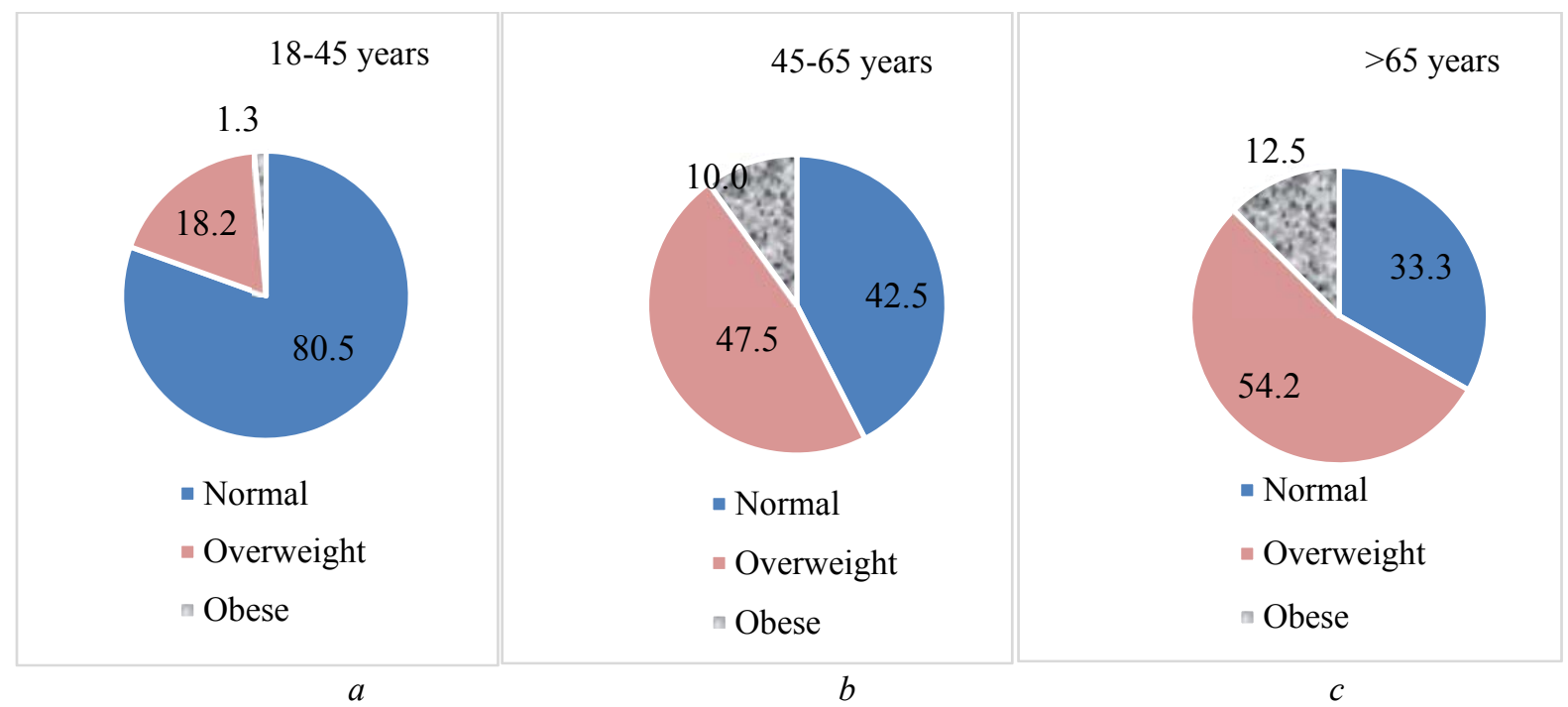

Fig. 1. Body mass index among females $(n=141), p=0.000: a$ - body mass index in the $18-45$ years old group; $b$ - body mass index in the 45-65 years old group; $c$ - body mass index in the group above 65 years 


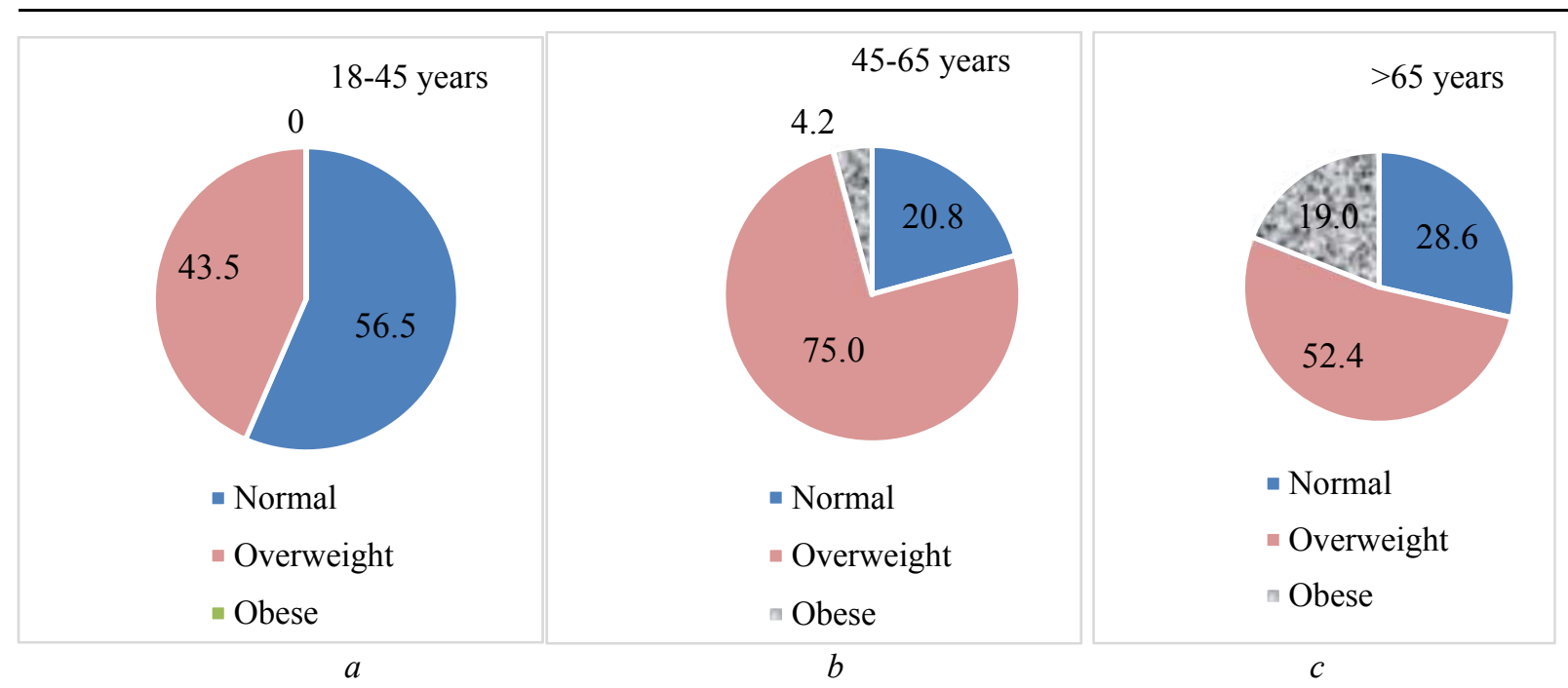

Fig. 2. Body mass index among males $(\mathrm{n}=107), \mathrm{p}=0.000: a$ - body mass index in the 18-45 years old group; $b$ - body mass index in the 45-65 years old group; $c$ - body mass index in the group above 65 years

Table 1

Constipation frequency in the study group, $n=250$

\begin{tabular}{|c|c|c|c|c|c|}
\hline \multirow{2}{*}{ Subject } & \multicolumn{3}{|c|}{ Constipation } & \multirow{2}{*}{ Total } & \multirow{2}{*}{$\mathrm{P}$} \\
\hline & Yes, n (\%) & No, $n(\%)$ & Occasionally, n (\%) & & \\
\hline \multicolumn{6}{|c|}{ Gender } \\
\hline Female & $21(14.7)$ & $57(39.9)$ & $65(45.5)$ & 143 & \multirow{2}{*}{0.220} \\
\hline Male & $11(10.3)$ & $54(50.5)$ & $42(39.3)$ & 107 & \\
\hline \multicolumn{6}{|c|}{ Age group } \\
\hline $18-45$ & $6(4.3)$ & $82(58.2)$ & $53(37.6)$ & 141 & \multirow{3}{*}{0.000} \\
\hline $45-65$ & $10(15.6)$ & $25(39.1)$ & $29(45.3)$ & 64 & \\
\hline$>65$ & $16(35.6)$ & $4(8.9)$ & $25(55.6)$ & 45 & \\
\hline \multicolumn{6}{|c|}{ Body mass index } \\
\hline Normal & $7(5.3)$ & $60(45.1)$ & $66(49.6)$ & 133 & \multirow{3}{*}{0.001} \\
\hline Overweight & $20(19.6)$ & $45(44.1)$ & $37(36.3)$ & 102 & \\
\hline Obese & $5(38.5)$ & $4(30.8)$ & $4(30.8)$ & 13 & \\
\hline
\end{tabular}

The similar influence of the age and body mass index by gender is presented in the Tab. 2. Higher percentage of males without constipation comparing with females were in 18-45 years old group (71.0\% vs $48.1 \%$ ).

The results showed that significant part of the participants suffered from constipation for a long period of time $(\mathrm{p}=0.007)$. More than one-half of the respondents $(62.5 \%, n=20)$ from the group of constant constipation confirmed that this problem existed longer than 5 years.
Similar answers $(55.1 \%, \mathrm{n}=59)$ were received from the study participants with occasional constipation, as this group of respondents reported the existing problem longer than 1 year $(30.8 \%, \mathrm{n}=33)$. Nutrition and physical activity was analyzed in order to establish the relationship with constipation. The results presented in the Fig. 3 show the influence of carbohydrate intake on constipation; however, there was no identified relationships with the consumption of vegetables (Fig. 4).

Table 2

Constipation frequency by the age and body mass index in females and males, $n=250$

\begin{tabular}{|c|c|c|c|c|c|}
\hline \multirow{2}{*}{ Subject } & \multicolumn{3}{|c|}{ Constipation } & \multirow{2}{*}{ Total } & \multirow{2}{*}{$\mathrm{P}$} \\
\hline & Yes, n (\%) & No, n (\%) & Occasionally, n (\%) & & \\
\hline \multicolumn{6}{|c|}{ Females } \\
\hline $18-45$ years & $5(6.3)$ & $38(48.1)$ & $36(45.6)$ & 79 & \multirow{3}{*}{0.000} \\
\hline $45-65$ years & $4(10.0)$ & $16(40.0)$ & $20(50.0)$ & 40 & \\
\hline$>65$ years & $12(50.0)$ & $3(12.5)$ & $9(37.5)$ & 24 & \\
\hline Normal & $7(8.0)$ & $35(40.2)$ & $45(51.7)$ & 87 & \multirow{3}{*}{0.024} \\
\hline Overweight & $11(23.9)$ & $16(34.8)$ & $19(41.3)$ & 46 & \\
\hline Obese & $3(37.5)$ & $4(50.0)$ & $1(12.5)$ & 8 & \\
\hline \multicolumn{6}{|c|}{ Males } \\
\hline $18-45$ years & $1(1.6)$ & $44(71.0)$ & $17(27.4)$ & 62 & \multirow{3}{*}{0.000} \\
\hline 45-65 years & $6(25.0)$ & $9(37.5)$ & $9(37.5)$ & 24 & \\
\hline$>65$ years & $4(19.0)$ & $1(4.8)$ & $16(76.2)$ & 21 & \\
\hline Normal & 0 & $25(54.3)$ & $21(45.7)$ & 46 & \multirow{3}{*}{0.004} \\
\hline Overweight & $9(16.1)$ & $29(51.8)$ & $18(32.1)$ & 56 & \\
\hline Obese & $2(40.0)$ & 0 & $3(60.0)$ & 5 & \\
\hline
\end{tabular}




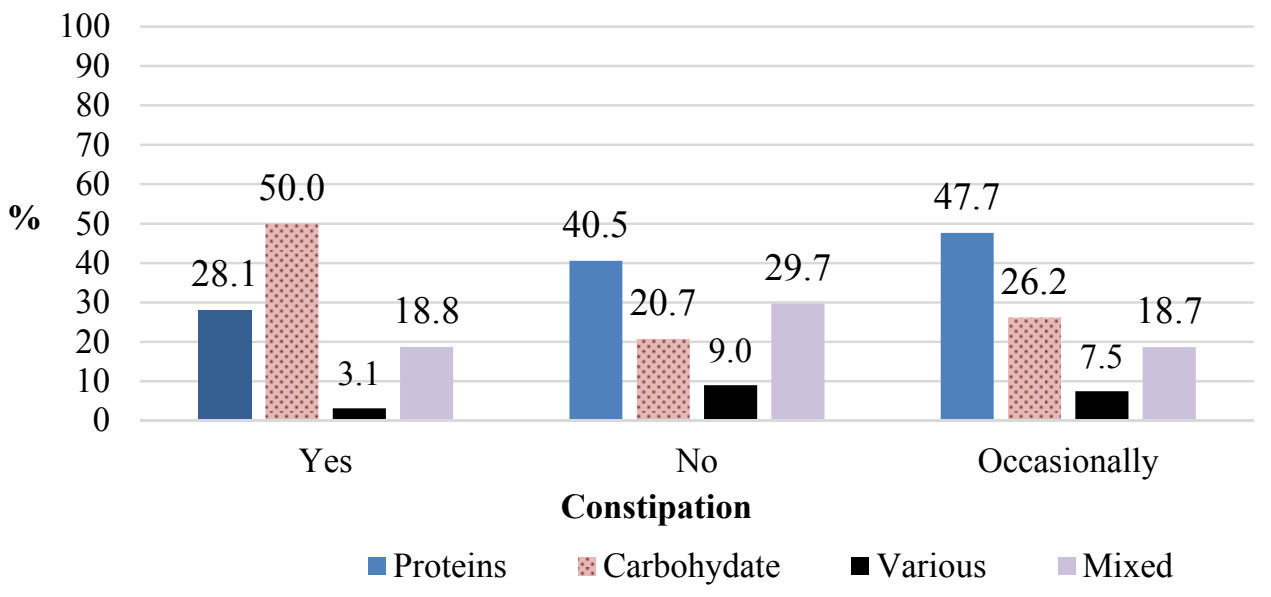

Fig. 3. Influence of nutrition on constipation in the study group ( $\mathrm{p}=0.023), \mathrm{n}=250$

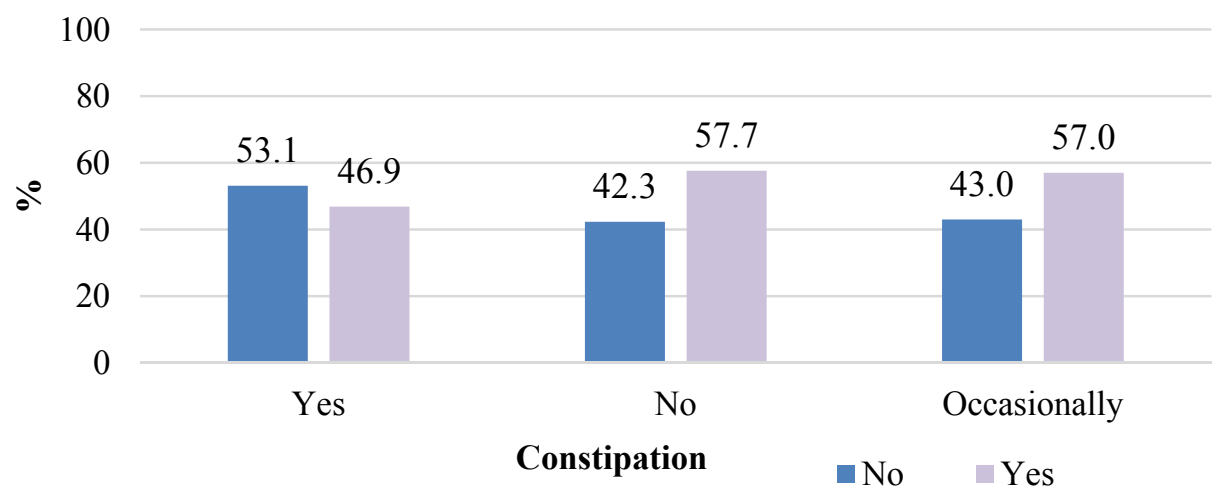

Fig. 4. Vegetables consumption by the respondents $(\mathrm{p}=0.535), \mathrm{n}=250$

While analysing habits to consume liquids and coffee/tea, it was identified that liquids consumption was associated with constant and occasional constipation (Fig. 5). A significantly higher number of participants used less than 2 litres of liquids.

The results in the Fig. 6 showed that coffee and/or tea consumption was not related to constipation in the study group - the respondents who did not consume these products reported constant constipation.

Influence of physical activity on constipation is presented in the Fig 7. According to the results, the respondents' motionless lifestyle was related to constant and occasional constipation $(75.0 \%$ and $41.1 \%$, respectively) $(\mathrm{p}<0.05)$. More respondents who performed exercises did not suffer from constipation.

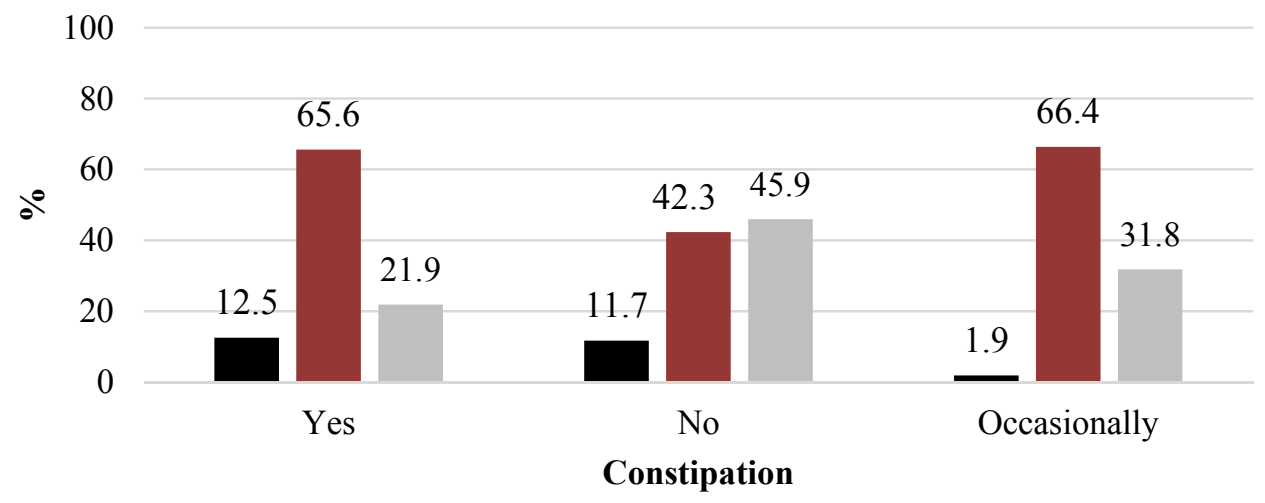

- Not answered $\quad$ Less than $21 \quad$ More than 21

Fig. 5. Liquids consumption by the respondents $(\mathrm{p}=0.001), \mathrm{n}=250$ 


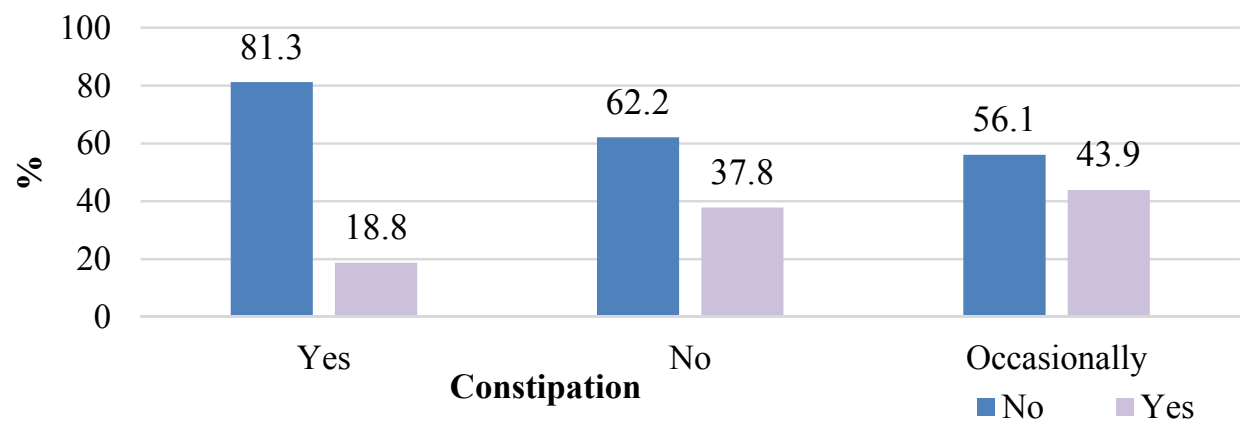

Fig. 6. Coffee and tea consumption by the respondents $(p=0.036), n=250$

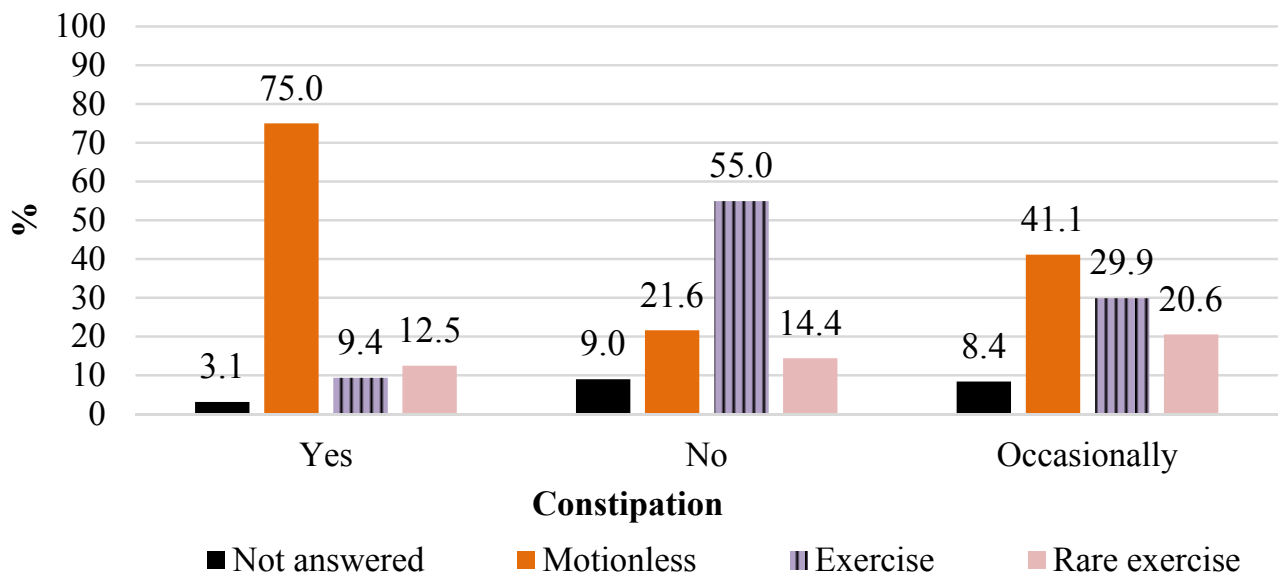

Fig. 7. Physical activity in the study group $(\mathrm{p}=0.000), \mathrm{n}=250$

An analysis of risk factors by age and body mass index in females and males was performed. Tab. 3 shows that carbohydrate dominated in the female groups $18-45$ years old $(43.0 \%)$ and above 65 years old $(66.7 \%)$, while the male in the groups $18-45$ years old and 45-65 years old preferred proteins (74.2\% and $70.8 \%$, respectively), vegetables consumption was higher in female groups comparing with the males. Liquids consumption was similar between genders, except for $18-45$ years old group $-53.2 \%$ of females used more than 2 litres liquids per day compared to $32.3 \%$ of males in the same age group. Physical activity was higher in $18-45$ years old group $-48.1 \%$ of females and $62.9 \%$ of males declared exercising. Motionless lifestyle was prevalent in the respondents' group above 65 years old (83.3\% females' vs $71.4 \%$ males).

Nutrition and physical activity was analyzed in relationship to body mass index (Tab. 4). Higher carbohydrate ("normal" and "obese" groups) and vegetables ("normal" and "overweight" groups) consumption by females if compared to proteins (all BMI groups) in males was identified. No significant difference by BMI groups in females and males was determined in liquids and coffee and/or tea consumption. Exercises were performed in "normal" BMI group (42.5\% of females vs. $56.5 \%$ of males).

Lifestyle factors (nutrition and physical activity) by age in females and males, $\mathrm{n}=250$

\begin{tabular}{|l|c|c|c|c|}
\hline \multicolumn{1}{|c|}{ Subject } & $18-45$ years, $\mathrm{n}(\%)$ & $45-65$ years, $\mathrm{n}(\%)$ & $>65$ years, $\mathrm{n}(\%)$ & $\mathrm{p}$ \\
\hline \multicolumn{3}{|c|}{ Females, $\mathbf{n}=\mathbf{1 4 3}$} \\
\hline Proteins & $15(19.0)$ & $12(30.0)$ & $3(12.5)$ \\
\hline Carbohydrate & $34(43.0)$ & $13(32.5)$ & $16(66.7)$ & 0 \\
\hline Various & $11(13.9)$ & $6(15.0)$ & $5(20.8)$ & \\
\hline Mixed & $19(24.1)$ & $9(22.5)$ & $11(45.8)$ & 0.083 \\
\hline Vegetables (no) & $18(22.8)$ & $13(32.5)$ & $13(54.2)$ & $3(12.5)$ \\
\hline Vegetables (yes) & $61(77.2)$ & $27(67.5)$ & $15(62.5)$ & 0.070 \\
\hline Liquids (not answered) & $5(6.3)$ & $3(7.5)$ & $6(25.0)$
\end{tabular}


Continuation of the Table 3

\begin{tabular}{|c|c|c|c|c|}
\hline Coffee/tea (no) & $45(57.0)$ & $29(72.5)$ & $21(87.5)$ & \multirow{2}{*}{0.013} \\
\hline Coffee/tea (yes) & $34(43.0)$ & $11(27.5)$ & $3(12.5)$ & \\
\hline Physical activity (not answered) & $9(11.4)$ & $2(5.0)$ & 0 & \multirow{4}{*}{0.000} \\
\hline Physical activity (motionless) & $15(19.0)$ & $23(57.5)$ & $20(83.3)$ & \\
\hline Physical activity (exercise) & $38(48.1)$ & $10(25.0)$ & $2(8.3)$ & \\
\hline Physical activity (rare exercises) & $17(21.5)$ & $5(12.5)$ & $2(8.3)$ & \\
\hline \multicolumn{5}{|c|}{ Males, $\mathbf{n}=107$} \\
\hline Proteins & $46(74.2)$ & $17(70.8)$ & $12(57.1)$ & \multirow{4}{*}{0.371} \\
\hline Carbohydrate & $2(3.2)$ & 0 & $2(50.0)$ & \\
\hline Various & $2(3.2)$ & 0 & 0 & \\
\hline Mixed & $12(19.4)$ & $7(29.2)$ & $7(33.3)$ & \\
\hline Vegetables (no) & $37(59.7)$ & $15(62.5)$ & $16(76.2)$ & \multirow{2}{*}{0.394} \\
\hline Vegetables (yes) & $25(40.3)$ & $9(37.5)$ & $5(23.8)$ & \\
\hline Liquids (not answered) & $8(12.9)$ & 0 & 0 & \multirow{3}{*}{0.038} \\
\hline Liquids (less than 2 l) & $34(54.8)$ & $16(66.7)$ & $18(85.7)$ & \\
\hline Liquids (more than 21 ) & $20(32.3)$ & $8(33.3)$ & $3(14.3)$ & \\
\hline Coffee/tea (no) & $30(48.4)$ & $13(54.2)$ & $17(81.0)$ & \multirow{2}{*}{0.033} \\
\hline Coffee/tea (yes) & $32(51.6)$ & $11(45.8)$ & $4(19.0)$ & \\
\hline Physical activity (not answered) & $3(4.8)$ & $4(16.7)$ & $2(9.5)$ & \multirow{4}{*}{0.000} \\
\hline Physical activity (motionless) & $8(12.9)$ & $11(45.8)$ & $15(71.4)$ & \\
\hline Physical activity (exercise) & $39(62.9)$ & $5(20.8)$ & $2(9.5)$ & \\
\hline Physical activity (rare exercises) & $12(19.4)$ & $4(16.7)$ & $2(9.5)$ & \\
\hline
\end{tabular}

Table 4

Lifestyle factors (nutrition and physical activity) by body mass index in females and males, $\mathrm{n}=248$

\begin{tabular}{|c|c|c|c|c|}
\hline Subject & Normal, n (\%) & Overweight, n (\%) & Obese, n (\%) & $\mathrm{p}$ \\
\hline \multicolumn{5}{|c|}{ Females, $n=141$} \\
\hline Proteins & $15(17.2)$ & $12(26.1)$ & $2(25.0)$ & \multirow{4}{*}{0.873} \\
\hline Carbohydrate & $39(44.8)$ & $19(13.5)$ & $4(50.0)$ & \\
\hline Various & $12(13.8)$ & $4(8.7)$ & $1(12.5)$ & \\
\hline Mixed & $21(24.1)$ & $11(23.9)$ & $1(12.5)$ & \\
\hline Vegetables (no) & $18(20.7)$ & $18(39.1)$ & $5(62.5)$ & \multirow{2}{*}{0.008} \\
\hline Vegetables (yes) & $69(79.3)$ & $28(60.9)$ & $3(37.5)$ & \\
\hline Liquids (not answered) & $5(5.7)$ & $4(8.7)$ & $2(25.0)$ & \multirow{3}{*}{0.300} \\
\hline Liquids (less than 2 l) & $41(47.1)$ & $25(54.3)$ & $3(37.5)$ & \\
\hline Liquids (more than 2 1) & $41(47.1)$ & $17(37.0)$ & $3(37.5)$ & \\
\hline Coffee/tea (no) & $51(58.6)$ & $36(78.3)$ & $7(87.5)$ & \multirow{2}{*}{0.032} \\
\hline Coffee/tea (yes) & $26(41.4)$ & $10(21.7)$ & $1(12.5)$ & \\
\hline Physical activity (not answered) & $7(8.0)$ & $4(8.7)$ & 0 & \multirow{4}{*}{0.006} \\
\hline Physical activity (motionless) & $26(29.9)$ & $23(50.0)$ & $8(100.0)$ & \\
\hline Physical activity (exercise) & $37(42.5)$ & $13(28.3)$ & 0 & \\
\hline Physical activity (rare exercises) & $17(19.5)$ & $6(13.0)$ & 0 & \\
\hline \multicolumn{5}{|c|}{ Males, $\mathbf{n}=\mathbf{1 0 7}$} \\
\hline Proteins & $35(76.1)$ & $36(64.3)$ & $4(80.0)$ & \multirow{4}{*}{0.238} \\
\hline Carbohydrate & $1(2.2)$ & $2(3.6)$ & $1(20.0)$ & \\
\hline Various & 0 & $2(3.6)$ & 0 & \\
\hline Mixed & $10(21.7)$ & $16(28.6)$ & 0 & \\
\hline Vegetables (no) & $28(60.9)$ & $35(62.5)$ & $5(100.0)$ & \multirow{2}{*}{0.219} \\
\hline Vegetables (yes) & $18(39.1)$ & $21(37.5)$ & 0 & \\
\hline Liquids (not answered) & $5(10.9)$ & $3(5.4)$ & 0 & \multirow{3}{*}{0.383} \\
\hline Liquids (less than 2 1) & $28(60.9)$ & $35(62.5)$ & $5(100.0)$ & \\
\hline Liquids (more than 2 1) & $13(28.3)$ & $18(32.1)$ & 0 & \\
\hline Coffee/tea (no) & $22(47.8)$ & $35(62.5)$ & $3(60.0)$ & \multirow{2}{*}{0.326} \\
\hline Coffee/tea (yes) & $24(52.2)$ & $21(37.5)$ & $2(40.0)$ & \\
\hline Physical activity (not answered) & $1(2.2)$ & $6(10.7)$ & $2(40.0)$ & \multirow{4}{*}{0.011} \\
\hline Physical activity (motionless) & $13(28.3)$ & $18(32.1)$ & $3(60.0)$ & \\
\hline Physical activity (exercise) & $26(56.5)$ & $20(35.7)$ & 0 & \\
\hline Physical activity (rare exercises) & $6(13.0)$ & $12(21.4)$ & 0 & \\
\hline
\end{tabular}




\section{Discussion}

In this study, constipation was evaluated according to the respondents' personal perspective. The $12.8 \%$ constipation rate was determined in the study group. A similar result $(12.3 \%)$ was identified in the study performed in seven countries [5]. The authors presented a higher constipation rate in women; however, that was not confirmed in this study. According to other studies, constipation affects $17 \%$ of adults in Europe, between $2 \%$ and $27 \%$ of the U.S. population [15]. The respondents were asked how they understand constipation. It turned out that $37.2 \%(n=93)$ of the respondents were not able to provide correct understanding, as according to them, constipation is confirmed when emptying is less than twice or once per week. This indicates that constipation might occur among the respondents with occasional constipation events as well. Inappropriate understanding of the problem by the respondents might worsen their quality of life.

The study identified that nutrition, liquids consumption and physical activity might be related to constipation. The half of females above 65 years old reported constant constipation. Analysis of this age group lifestyle showed consumption of carbohydrates, less than 2 litres of liquids per day and low mobility lifestyle. Also, not sufficient consumption of fluids and low mobility lifestyle dominated in the groups with occasional constipation (45-45 years old group of females and $>65$ years old of males), although, scientific publications do not have common conclusion regarding the fluids intake for constipation relief $[12,18]$.

The presence of constipation has a negative influence on the individual's health. However the study results showed that respondents do not consider this disorder adequately, as only $60(24.0 \%)$ of the respondents sought out for information about their constipation, those were $16(50.0 \%)$ persons from the group with constant constipation and $31(29.0 \%)$ with the occasional constipation events. The consultation by health care specialists (pharmacists, family doctors) was indicated by 9 (15.0\%) and self-education by $33(55.0 \%)$ of respondents. The pharmacists should be more involved in patients' care. A study in Japan confirmed that patients are satisfied with the pharmacists' consultation [19].

The respondents reported factors related to the constipation were malnutrition (mentioned by 230 respondents $(92.0 \%)$ ), lack of physical activity - 237 $(94.8 \%)$, insufficient fluid intake - $238(95.2 \%)$, the senior age was reported by almost all respondents $242(96.8 \%)$. Even though the individuals were aware of the possible risk factors, their lifestyle has shown an opposite approach. Even 134 (96.4\%) respondents from 139 persons who consume less than 21 of liquids named the lack of fluids as the reason for their constipation. As well, lack of physical activity was in $95.6 \%$ of respondents with low mobility lifestyle.

The study identified that $43(30.9 \%)$ respondents with constant and occasional constipation did not take any measures to minimize the constipation events, $27(19.4 \%)$ - used non-pharmaceutical means for this problem, however, the majority of the respondents preferred to take pharmaceutical products (medication and food supplements). Conversely, a study in seven countries showed the opposite; respondents generally preferred non-medication alleviation of constipation [45]. A study in Austria found that meals enriched with dietary fibers reduces the use of laxatives by $59 \%$ compared to the control group [20]. A balanced, high-fiber diet, adequate intake of fluid, and physical activity are the key to preventing mild to moderate constipation [21]. Considering these results, pharmacists should be aware that their patients' education on lifestyle change could be included in recommendations for constipation avoidance and help the patients to choose the appropriate medication.

Due to a limited number of respondents with constant constipation, it was not possible to analyse lifestyle effects according to the age and exact body mass index. This study indicated only possible trends, as the risk factors were analysed separately by age and body mass index. The results showed that age and BMI had an association with constipation similarly in both genders. A further study needs to be implemented, involving higher number of participants with constipation understanding the inclusion criterion should be clarified for the study participants. In that case, more precise results while analysing risk factors could be obtained.

\section{Conclusions}

The consumption of carbohydrates, inadequate intake of fluids and low mobility lifestyle were identified as risk factors for constipation in this study. Lifestyle modification recommendations might be included in the pharmacists' consultation. As the study participants did not have a correct understanding of their constipation, the pharmacist should consider this when providing consultation.

\section{Conflict of interest} declare.

\section{References}

1. Peppas, G., Alexiou, V. G., Mourtzoukou, E., Falagas, M. E. (2008). Epidemiology of constipation in Europe and Oceania: a systematic review. BMC Gastroenterology, 8 (1). doi: http://doi.org/10.1186/1471-230x-8-5

2. Cook, I. J., Talley, N. J., Benninga, M. A., Rao, S. S., Scott, S. M. (2009). Chronic constipation: overview and challenges. Neurogastroenterology \& Motility, 21, 1-8. doi: http://doi.org/10.1111/j.1365-2982.2009.01399.x

3. De Giorgio, R., Ruggeri, E., Stanghellini, V., Eusebi, L. H., Bazzoli, F., Chiarioni, G. (2015). Chronic constipation in the elderly: a primer for the gastroenterologist. BMC Gastroenterology, 15 (1). doi: http://doi.org/10.1186/s12876-015-0366-3

4. Suares, N. C., Ford, A. C. (2011). Systematic review: the effects of fibre in the management of chronic idiopathic constipation. Alimentary Pharmacology \& Therapeutics, 33 (8), 895-901. doi: http://doi.org/10.1111/j.1365-2036.2011.04602.x

5. Wald, A., Scarpignato, C., Müeller- Lissner, S., Kamm, M. A., Hinkel, U., Helfrich, I. et. al. (2008). A multinational survey of prevalence and patterns of laxative use among adults with self-defined constipation. Alimentary Pharmacology and Therapeutics, 28, 917-930. doi: http://doi.org/10.1111/j.1365-2036.2008.03806.x 
6. Emmanuel, A., Mattace-Raso, F., Neri, M. C., Petersen, K.-U., Rey, E., Rogers, J. (2016). Constipation in older people: A consensus statement. International Journal of Clinical Practice, 71 (1), e12920. doi: http://doi.org/10.1111/ijcp.12920

7. Quigley, E. M. M., Vandeplassche, L., Kerstens, R., Ausma, J. (2009). Clinical trial: the efficacy, impact on quality of life, and safety and tolerability of prucalopride in severe chronic constipation - a 12-week, randomized, double-blind, placebo-controlled study. Alimentary Pharmacology \& Therapeutics, 29 (3), 315-328. doi: http://doi.org/10.1111/j.1365-2036.2008.03884.x

8. Foxx-Orenstein, A. E., McNally, M. A., Odunsi, S. T. (2008). Update on constipation: One treatment does not fit all. Cleveland Clinic Journal of Medicine, 75 (11), 813-823. doi: http://doi.org/10.3949/ccjm.75.11.813

9. Savica, R., Carlin, J. M., Grossardt, B. R., Bower, J. H., Ahlskog, J. E., Maraganore, D. M. et. al. (2009). Medical records documentation of constipation preceding Parkinson disease: A case-control study. Neurology, 73 (21), 1752-1758. doi: http://doi.org/10.1212/wnl.0b013e3181c34af5

10. Onder, G., Liperoti, R., Fialova, D., Topinkova, E., Tosato, M. et. al. (2012). Polypharmacy in Nursing Home in Europe: Results From the SHELTER Study. The Journals of Gerontology Series A: Biological Sciences and Medical Sciences, 67A (6), 698704. doi: http://doi.org/10.1093/gerona/glr233

11. Liu, L. W. (2011). Chronic Constipation: Current Treatment Options. Canadian Journal of Gastroenterology, 25, 22B-28B. doi: http://doi.org/10.1155/2011/930108

12. Rao, S., Go, J. T. (2010). Update on the management of constipation in the elderly: new treatment options. Clinical Interventions in Aging, 5, 163-171. doi: http://doi.org/10.2147/cia.s8100

13. Dimidi, E., Christodoulides, S., Fragkos, K. C., Scott, S. M., Whelan, K. (2014). The effect of probiotics on functional constipation in adults: a systematic review and meta-analysis of randomized controlled trials. The American Journal of Clinical Nutrition, 100 (4), 1075-1084. doi: http://doi.org/10.3945/ajen.114.089151

14. Johanson, J. F., Kralstein, J. (2007). Chronic constipation: a survey of the patient perspective. Alimentary Pharmacology \& Therapeutics, 25 (5), 599-608. doi: http://doi.org/10.1111/j.1365-2036.2006.03238.x

15. Müller-Lissner, S., Tack, J., Feng, Y., Schenck, F., Specht Gryp, R. (2012). Levels of satisfaction with current chronic constipation treatment options in Europe - an internet survey. Alimentary Pharmacology \& Therapeutics, 37 (1), 137-145. doi: http://doi.org/10.1111/apt.12124

16. Gao, R., Tao, Y., Zhou, C., Li, J., Wang, X., Chen, L. et. al. (2019). Exercise therapy in patients with constipation: a systematic review and meta-analysis of randomized controlled trials. Scandinavian Journal of Gastroenterology, 54 (2), 169-177. doi: http://doi.org/10.1080/00365521.2019.1568544

17. Asakura, K., Masayasu, S., Sasaki, S. (2017). Dietary intake, physical activity, and time management are associated with constipation in preschool children in Japan. Asia Pacific Journal of Clinical Nutrition, 26, 118-129.

18. Murakami, K., Sasaki, S., Okubo, H., Takahashi, Y., Hosoi, Y., Itabashi, M. (2006). Association between dietary fiber, water and magnesium intake and functional constipation among young Japanese women. European Journal of Clinical Nutrition, 61 (5), 616-622. doi: http://doi.org/10.1038/sj.ejcn.1602573

19. Shibata, K., Matsumoto, A., Nakagawa, A., Akagawa, K., Nakamura, A., Yamamoto, T., Kurata, N. (2016). Use of Pharmacist Consultations for Nonprescription Laxatives in Japan: An Online Survey. Biological and Pharmaceutical Bulletin, 39 (11), 1767-1773. doi: http://doi.org/10.1248/bpb.b16-00008

20. Sturtzel, B., Elmadfa, I. (2008). Intervention with Dietary Fiber to Treat Constipation and Reduce Laxative Use in Residents of Nursing Homes. Annals of Nutrition and Metabolism, 52 (1), 54-56. doi: http://doi.org/10.1159/000115351

21. Eoff, J. C. (2008). Optimal Treatment of Chronic Constipation in Managed Care: Review and Roundtable Discussion. Journal of managed care pharmacy, 14 (9), 1-15.

Received date 19.11.2019

Accepted date 06.12.2019

Published date 30.12.2019

Rima Minkutè, PhD, Lecturer, Department of Clinical Pharmacy, Lithuanian University of Health Sciences, Sukilèlių str., 13, Kaunas, Lithuania, 50162

E-mail: rima.minkute@1smuni.lt

Indrè Andrijauskaitè, Postgraduate Student, Department of Clinical Pharmacy, Lithuanian University of Health Sciences, Sukilèlių str., 13, Kaunas, Lithuania, 50162

E-mail: indreandr5@gmail.com

Vitalis Briedis. PhD, Professor, Head of the Department, Department of Clinical Pharmacy, Lithuanian University of Health Sciences, Sukilèlių str., 13, Kaunas, Lithuania, 50162

E-mail: vitalis.briedis@1smuni.lt; 